\title{
STATISTICAL COORDINATES OF YOUNG ENTREPRENEURS IN THE ROMANIAN BUSINESS ENVIRONMENT IN THE NORTH-EAST REGION
}

\author{
Daniela Mihaela NEAMȚU ${ }^{a^{*}}$, Cristian Valentin HAPENCIUC \\ ${ }^{a, b}$ University Stefan cel Mare of Suceava, Romania
}

\begin{abstract}
The terms "entrepreneurship "and "entrepreneur" have become increasingly used around the world because entrepreneurship tends to be associated with the economic development and well-being of a nation. When we refer to entrepreneurship education, we must consider not only formal education, which is very important in fact business administration, marketing, sales, human resources, communication and PR, finance but also getting in touch with entrepreneurial models. Therefore, entrepreneurship education is different from traditional academic education and involves the soading of unique aspirations and attitudes to entrepreneurs, which can only develop through contact with entrepreneurial success stories and through contact with entrepreneurs who have succeeded. But just as importantly, young people need to understand not only a romanticised interpretation of entrepreneurship, but also the negative aspects of starting a business. Comparing with entrepreneurs from other countries we are among the last to see the potential of success stories in entrepreneurship education and we are the first by the perceived importance of formal tertiary education. This last type of education could best be supported by government measures, because the universities in Romania are predominantly "state-owned". The general objective of the present research is represented by identifying the profile of young people from the North-East area who intend to open a business in the near / distant future in order to be able to get an overview of the interest that young people show in the business environment. Within quantitative methods of data processing, the basic is the sociological survey, and the main tool for collecting data is the questionnaire. All study tools are administered and applied online, and the collection and centralization of data is done automatically and securely.
\end{abstract}

KEYWORDS: entrepreneurship, entrepreneurial culture, young entrepreneurs, business environment

DOI: 10.24818/IMC/2021/01.06

\section{INTRODUCTION}

Being a successful entrepreneur is also taught, in addition, the initiation and development of one's own business is permanently learned, but best when one's own experiences and those of others, including mistakes, are considered with great care. Anyone can start their own business and the easiest part is setting up a company, (Ciobanu, et. all, 2015).

The main advantage of entrepreneurs is the ideas and the desire to create something that will be successful, the project being exclusively theirs. They develop the idea and must possess the necessary knowledge, to invest their own creativity in the success of the company in order to be able to realize their dreams (Rothbard, M.N., 1997).

The entrepreneur must possess a wealth of knowledge, skills and competences, but also leadership, commitment, responsibility and dynamism.

\footnotetext{
${ }^{*}$ Corresponding author. E-mail address: dana.neamtu@usm.ro
} 
Among the essential qualities of a successful entrepreneur are strong personality, perseverance and persistence, attitude and imagination developed, self-respect, curiosity and motivation (Collins J., 2010). All entrepreneurs have in common the passion for what they do, passion for their own ideas and the desire to achieve them on the market. In addition, all entrepreneurs want to control their destiny and not tell them what to do.

The work of entrepreneurs has a strong impact on the world because, even if they are not the ones who invent new things, in the end they are the ones who make things move and the world to progress. They are the ones who introduce new technologies, promote new products, stimulate the discovery of new resources and mobilize capital. In addition, it is entrepreneurs who provide a job for most of the world's population. (Cowen T., 2012).

Among the advantages/benefits that entrepreneurs can list/identify in this career direction, there are:

$>$ the possibility of working in a field that they are passionate about,

$>$ the freedom to choose for themselves the team to work with,

$>$ the fact that they have no bosses and have freedom of decision,

$>$ the opportunity to earn more money and financial independence,

$>$ flexible schedule

An entrepreneur is the person who wants to realize his business ideas. These ideas are always based on significant and detailed knowledge about certain industries and markets, customer needs, technology, distribution and sales methods. The entrepreneur is the person who manages to successfully run his own business (Fuhrman J., 2012).

In the literature, entrepreneurial culture is presented as an important factor in achieving entrepreneurial success. The concept of entrepreneurial culture is defined as a totality of principles, methods, techniques and styles of carrying out the activity of entrepreneurship, in accordance with the social-legal norms, ethical and moral rules existing in the society. Thus, the key element of the entrepreneurial culture is the observance of internal and external organizational ethical norms of behavior - models of expected behavior (Marinescu, M., Botea, M., 2017). Entrepreneurial culture is formed under the influence of certain factors, such as family, entrepreneurial personal experience, faith, entrepreneurial culture in the social ecosystem, culture of investors and other partners, etc. (Jelescu P., Elpujan O., 2016).

It is considered that the characteristic elements of the entrepreneurial culture of successful entrepreneurs are the following:

- His conviction in the viability and profitability of the business idea, in the product that will be launched and that will induce changes in the environment.

- Independence, diligence, self-confidence, healthy individualism.

- Knowledge and skills on the organization of the work of teams, formed to achieve the goals. A leader's behavior presupposes the ability to take responsibility for others and receive decisions independently as a result of situation analysis.

- It targets the needs of people, that is, the ability to observe and work patiently with people's problems, solving specific everyday problems and tasks; Innovation, that is, the ability to seek change and react to them by creating a new product.

- Aiming for the result, i.e., the ability to visualize the entrepreneurial process from start to finish, which implies the focused and consistent construction of the order of tasks to be performed.

- Understanding the necessity of risk and resistance to stress, because an entrepreneur at risk should not resort to the chaotic search for solutions but rely on well-thought-out logical actions.

- It aims at continuous education as a tool of your own development and growth of the business.

- The ability and desire to teach others is the key element of a leader's culture, but this is impossible to achieve without its own disposition to improve skills, both managerial and professional;

- Waiting for economic freedom in the conduct of its business activity. According to von Hayek's definition, "economic freedom is the freedom of any activity that includes the right to choose and take the risk and responsibility for the choice made". (Roibu P. A., 2019). 
- Respecting the legality of carrying out the entrepreneurial activity by all its subjects, this being important not only for entrepreneurs, but also for all citizens of the country.

- Strict fulfillment of obligations and responsibilities, which implies compliance with legal norms and contractual relations.

Entrepreneurship education in the university begins with exposing as many students as possible to the idea of entrepreneurship (associated risk, how to identify opportunities, innovation as an essential skill). This type of exposure is not meant to turn students into entrepreneurs, but to help them assess whether they want to become entrepreneurs. After these first steps, those who think they want to become entrepreneurs can get involved in activities such as that of incubators and business accelerators. (Neamţu D. M., 2017).

\section{BUSINESS ENVIRONMENT - LIMITS AND PERSPECTIVES}

According to the statistics provided by the National Trade Register Office (Table no. 1) in 2021, there has been an increase in the registrations of new companies or IF /II/ PFAs due to the fact that 2020 was a pandemic year, and the economy is rebounding with small steps and the vast majority of companies have resumed their activity.

Table 1. Registrations made between 01.01.2021-30.04.2021 compared to the same period of last year

\begin{tabular}{|c|c|c|c|c|c|c|c|c|c|c|c|c|}
\hline \multirow[t]{2}{*}{ County } & \multicolumn{5}{|c|}{$\begin{array}{l}\text { Registrations in the period 01.01.2021- } \\
\text { 30.04.2021 }\end{array}$} & \multicolumn{6}{|c|}{$\begin{array}{l}\text { Registrations in the period 01.01.2021- } \\
\text { 30.04.2021 }\end{array}$} & \multirow[t]{2}{*}{ Dynamics } \\
\hline & IF & II & PFA & SRL & $\begin{array}{l}\text { General } \\
\text { total }\end{array}$ & CA & IF & II & PFA & SRL & $\begin{array}{l}\text { General } \\
\text { total }\end{array}$ & \\
\hline Suceava & 11 & 13 & 208 & 864 & 1.196 & 2 & 3 & 44 & 125 & 397 & 571 & $109,46 \%$ \\
\hline
\end{tabular}

Source: own elaboration based on the data taken

https://www.onrc.ro/index.php/ro/statistici?id=243

The same source also provides us with information on the age of the associates/holders of the companies or IF/II/PFAs, noting that the fewest are those in the category up to 29 years.

Table 2. Statistics of active legal entities according to the age of the shareholders / shareholders as of 30.04.2021

\begin{tabular}{|c|c|c|c|c|c|c|c|c|c|c|c|c|}
\hline \multirow[t]{3}{*}{ County } & \multirow{3}{*}{$\begin{array}{l}\text { No. } \\
\text { legal } \\
\text { people }\end{array}$} & \multirow{3}{*}{$\begin{array}{c}\text { No of } \\
\text { shareholders }\end{array}$} & \multicolumn{10}{|c|}{$\begin{array}{l}\text { Distribution of shareholders by age } \\
\end{array}$} \\
\hline & & & \multicolumn{2}{|c|}{$\begin{array}{l}\text { Up to } 29 \\
\text { years old }\end{array}$} & \multicolumn{2}{|c|}{ 30-39 years } & \multicolumn{2}{|c|}{$40-49$ years } & \multicolumn{2}{|c|}{ 50-59 years } & \multicolumn{2}{|c|}{ over 60 years } \\
\hline & & & No. & $\%$ & No. & $\%$ & No. & $\%$ & No. & $\%$ & No. & $\%$ \\
\hline Suceava & 21.550 & 30.547 & 3.246 & 10,63 & 8.156 & 26,7 & 8.360 & $19,49 \%$ & 5.953 & $19,49 \%$ & 4.832 & $15,82 \%$ \\
\hline
\end{tabular}

Source: own elaboration based on the data taken

https://www.onrc.ro/index.php/ro/statistici?id=243

Table 3. Statistics of PFA/II/IF PFA/II/IF active according to the age of the holders/members as of 30.04.2021

\begin{tabular}{|c|c|c|c|c|c|c|c|c|c|c|c|c|}
\hline \multirow{3}{*}{ County } & \multirow{3}{*}{$\begin{array}{c}\text { No.PFA/ } \\
\text { II/IF } \\
\text { assets }\end{array}$} & \multirow{3}{*}{$\begin{array}{c}\text { No of } \\
\text { holders/ } \\
\text { members } \\
\text { of } \\
\text { PFA/II/IF }\end{array}$} & \multicolumn{10}{|c|}{ Distribution of members by age } \\
\hline & & & \multicolumn{2}{|c|}{$\begin{array}{c}\text { Up to } 29 \\
\text { years old }\end{array}$} & \multicolumn{2}{|c|}{ 30-39 years } & \multicolumn{2}{|c|}{ 40-49 years } & \multicolumn{2}{|c|}{$50-59$ years } & \multicolumn{2}{|c|}{ over 60 years } \\
\hline & & & No. & $\%$ & No. & $\%$ & No. & $\%$ & No. & $\%$ & No. & $\%$ \\
\hline Suceava & 10.230 & 11.888 & 1.148 & 9,66 & 2.619 & 22,03 & 3.349 & 28,17 & 2.757 & 23,19 & 2.015 & 16,95 \\
\hline
\end{tabular}

Source: own elaboration based on the data taken

https://www.onrc.ro/index.php/ro/statistici? id $=243$

Note: The companies registered in the Trade Register that have not declared their suspension of activity and are not in any of the states that can lead to the loss of legal personality are considered 
active from a legal point of view. From the total number of companies registered in the Trade Register, there were excluded companies with temporary suspension

of activity, branches without legal personality, deregistered companies, companies in dissolution, liquidation, legal reorganization, bankruptcy, insolvency.

As we see in Tables 2 and 3, about 30\% of start-ups by April 2021 have associates/administrators up to the age of 40 . Given the small percentage of companies set up by young people, a state intervention is required through government programs to encourage and support young people in the development of business ideas. This is also the reason why we chose to research the intentions of young people in opening a business.

\section{RESEARCH METHODOLOGY}

It is no secret that young Romanians increasingly want to become businessmen, but they do not know what the starting point is and they do not have enough confidence in their own forces. In order to fulfill their dream, many of them also participate in various information and entrepreneurial training courses to learn from specialists what are the steps they need to take in this regard.

\subsection{Purpose, objectives and assumptions of the research}

The general purpose of this research is represented by Identifying the profile of young people from Suceava who intend to open a business in the near / distant future in order to make us an overview of the interest that young people show in the business environment. In order to achieve the general goal of the research we have defined a series of specific objectives such as:

O1: Identifying the most attractive areas where young people want to start a business

$\mathrm{O} 2$ : Identifying the sources used in opening the business

O3: Identifying the advantages and disadvantages of opening a new business

O4: Identifying the level of education / specialization of young people who intend to become entrepreneurs.

\subsubsection{Determination of sample size}

In order to determine the sample size, we turned to the website of the National Institute of Statistics Suceava and the website of the www.ecoduri.com from where we extracted the total number of young people, by summing up the number of young people by age categories. The sampling method used is random, probabilistic sampling, as we have given chances to be included in the sample to all young people in Suceava in the number of 21,134 people.

We resorted to the sampling method because we wanted to follow the measurement of some variables and the determination of specific indicators in which to observe their evolution and to identify the desires of young people in setting up a business on their own.

The volume of the sample, in this case, depends on 2 elements as we know data about the population studied, namely:

- $\quad$ Maximum permissible error $=5 \%$ in our case

- Probability of guaranteeing the result $=95 \%$ - confidence coefficient in responses

$$
\mathrm{n}=\frac{z^{2} x p(100-p)}{e^{2}} \rightarrow \text { sample volume }
$$

$\mathrm{z}=1,96$ pentru $\mathrm{p}=95 \%$

$$
\mathrm{e}=5 \%
$$

$$
\begin{aligned}
& \mathrm{n}=\frac{1,96^{2} x 0,5(1-0,5)}{0,05^{2}}=384 \\
& \mathrm{~N}=\frac{N-n}{N-1}=\frac{21.134-384}{21.134-1}=\frac{20.750}{21.133}=0,98
\end{aligned}
$$

$\mathrm{N}=21.134$

\section{$\rightarrow 0,98 \times 384=376$ observation units}


The study was conducted based on a sample of 207 people, young people aged between 18 and 35, approached online. In this respect, in determining the sample size of the research, there are several conditioning factors, such as: the degree of homogeneity of the community, the size of the representativeness error and the probability of guaranteeing the results. The sampling method chosen is random, probabilistic sampling, which is identified with the principle of ensuring equal opportunities for the inclusion in the sample of all respondents. The sample is relevant because the persons included possess the essential characteristics of the population targeted by our research. The questionnaire was distributed in the form of an access link using the google forms platform, the host of the questions, through email messages, telephone, verbally face to face and displayed on different social networks. (Chelcea S., 1975)

During the distribution of the questionnaires, we have continuously checked the way in which the data collection is to be conducted in order to prevent, as far as possible, the occurrence of significant errors. At this stage of the study we faced a certain reluctance on the part of young people to answer the questionnaire, this being due to: lack of time, indifference to research, large volume of questionnaires distributed simultaneously in the online environment, in general or other problems of a personal nature. We consider that this is the reason why we have received only 207 responses out of the more than 300 messages sent individually and from the link posted on various social networks.

The relevance of the investigated topic is justified based on the following hypotheses of the research:

General assumptions - the role of printing the basic directions of research

Hypothesis 1: Most young people with entrepreneurship education want to open a business.

Hypothesis 2: Most young people in Suceava without a job want to open a business.

Hypothesis 3: Most young people from Suceava choose to start a business in the field of service provision.

Hypothesis 4: The average amount invested by young people who want to open a business is 20,000 euros.

Statistical assumptions - consider measurable aspects of the research being established in relation to certain parameters of the population

Hypothesis 1: At most $40 \%$ of young people with entrepreneurship education want to open a business.

Hypothesis 2: At least $60 \%$ of the young people surveyed from Suceava without a job want to open a business.

Hypothesis 3: At most $80 \%$ of the young people surveyed want to open a business in the field of Services provision.

Hypothesis 4: The amount that young people want to invest in a new business is at most 25,000 euros.

\subsection{Research tool}

In order to be able to directly investigate all the mentioned aspects that concern the general and specific objectives, we have developed a questionnaire containing 13 closed questions. These questions contain pre-fixed variants of answer, the person questioned will choose the one that seems to resonate with his opinion. The questions also involved a single answer or multiple answers, without the possibility of introducing a new variant of answer. The reasons why we considered it appropriate to use this type of questions in our research (advantages) refers to the fact that, through them, the answers are easily recorded, the processing of the results is fast, the choice of the appropriate answer is made easily and last but not least, in this way errors are reduced or even avoided. In the self-administered questionnaire we avoided using too many questions especially for fear of boring the subjects participating in its completion. The 13 questions were formulated in a clear and concise way and we turned to the following types of questions: dihtomical questions; 
scaled questions; filter questions; funnel questions turned away; identifying questions. The questionnaire was drawn up on 4 different sections, but which have continuity and relevance in research. In the beginning part of the questionnaire, we presented the team, the general objective of the research and we assured the subjects participating in the research that the data obtained by filling in the questionnaires are confidential and anonymous. The first section of the survey included 2 questions identifying the status of the questioned topic as well as his intention to develop a business in the near or distant future. These questions are representative of our research as the answers given, at least to the second question, serve as a starting point for the other questions. These questions were mandatory in order to be able to make a clear assessment of the distinct answers in these categories. The second part of the survey had 5 questions regarding: the field of activity in which young people want to open a business, the benefit of training courses in entrepreneurship, the source of provenance of the money needed to start the business and last but not least the amount they consider they need to start the business. Part three contains various questions meant to provide us with answers that are equally necessary for the research itself, giving us the opinions of the subjects on issues that can create problems for a new entrepreneur and the advantages and disadvantages of opening a business in the chosen field. In the last part, we focused on some identifying questions that served us to analyze, interpret and correlate the answers in the questionnaire. These questions are those that concern the age and level of education and have a great significance for the research undertaken because we can better define the categories of young people who want to open a business.

\subsection{Processing and interpretation of results}

Within the chosen research project, the community is represented by the number of young people aged between 18 and 35 years old in Suceava. Based on the centralization of the answers to the questions in the questionnaire, we made graphs and diagrams to some of the most important questions.

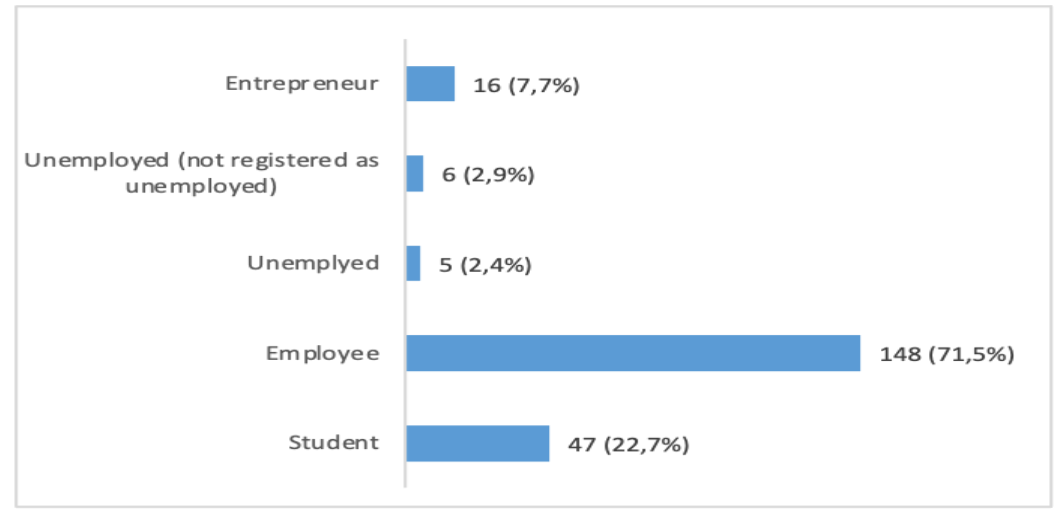

Figure 1. Status of respondents

Source: own elaboration

148 of the young people who participated in the survey are mostly young employees. In second place are young people who are students, and in the last positions are the unemployed and unemployed young people (not registered as unemployed). 


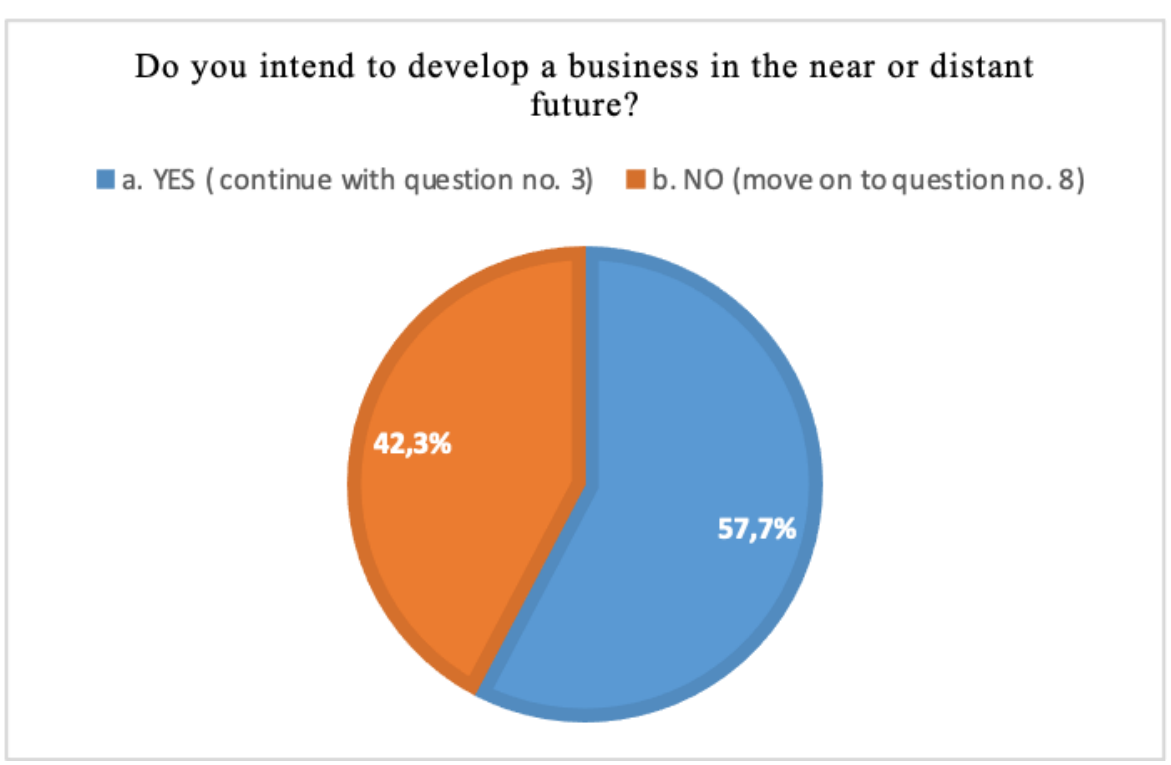

Figure 2. The intention to develop a business

Source: own elaboration

Only $57.7 \%$ of young people plan to open a business in the near future, and the difference of $42.3 \%$ is represented by young people who have no intention of becoming entrepreneurs.

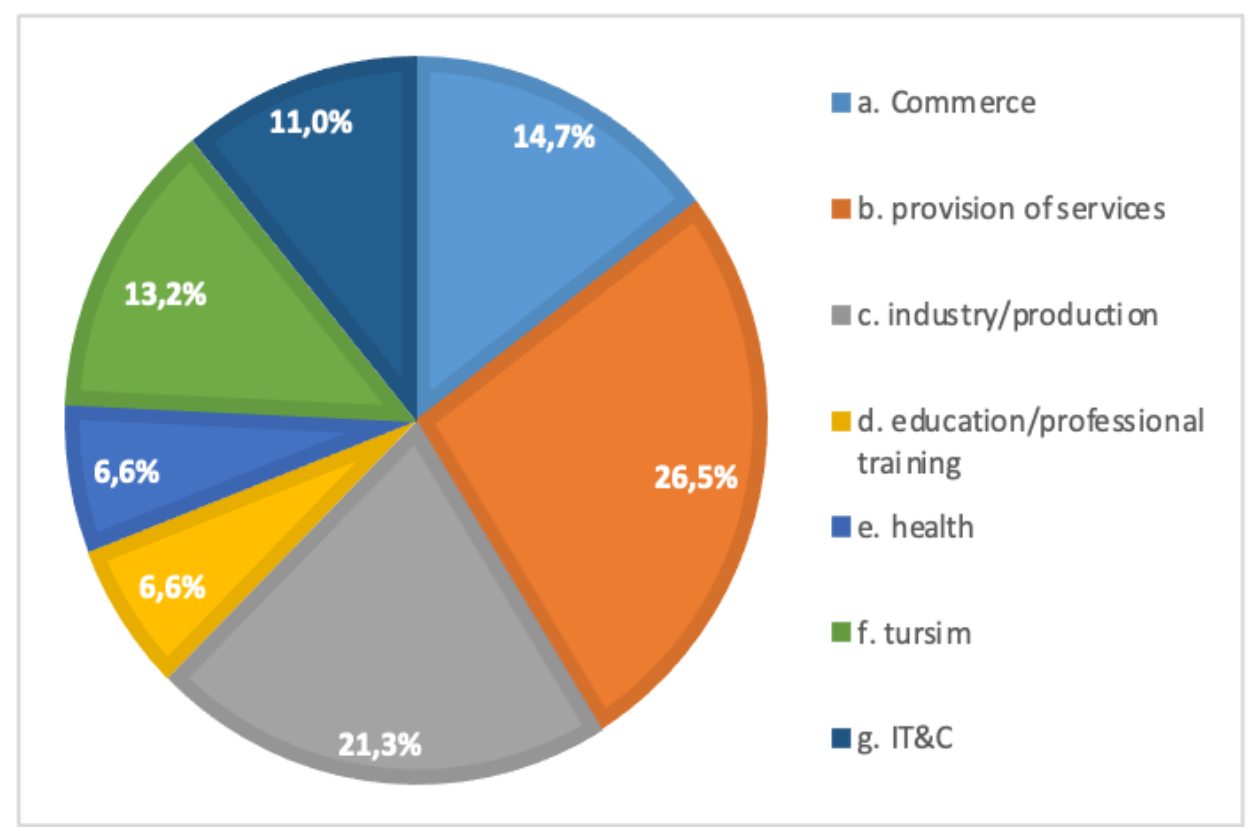

Figure 3. The field of starting a business

Source: own elaboration

Of the 136 young people who answered this question, it seems to be expected that the desire to open a business in the field of Services is the majority, where $26.5 \%$ of the young survey participants want to open a business. Industry / Production is on the second place, at a difference of only 5\% compared to the field on the first place, on the next positions being followed by Trade (14.7\%),

Tourism (13.2\%), IT\&C (11\%) and on the last places, with the same percentage of only $6.66 \%$ being education and health. 


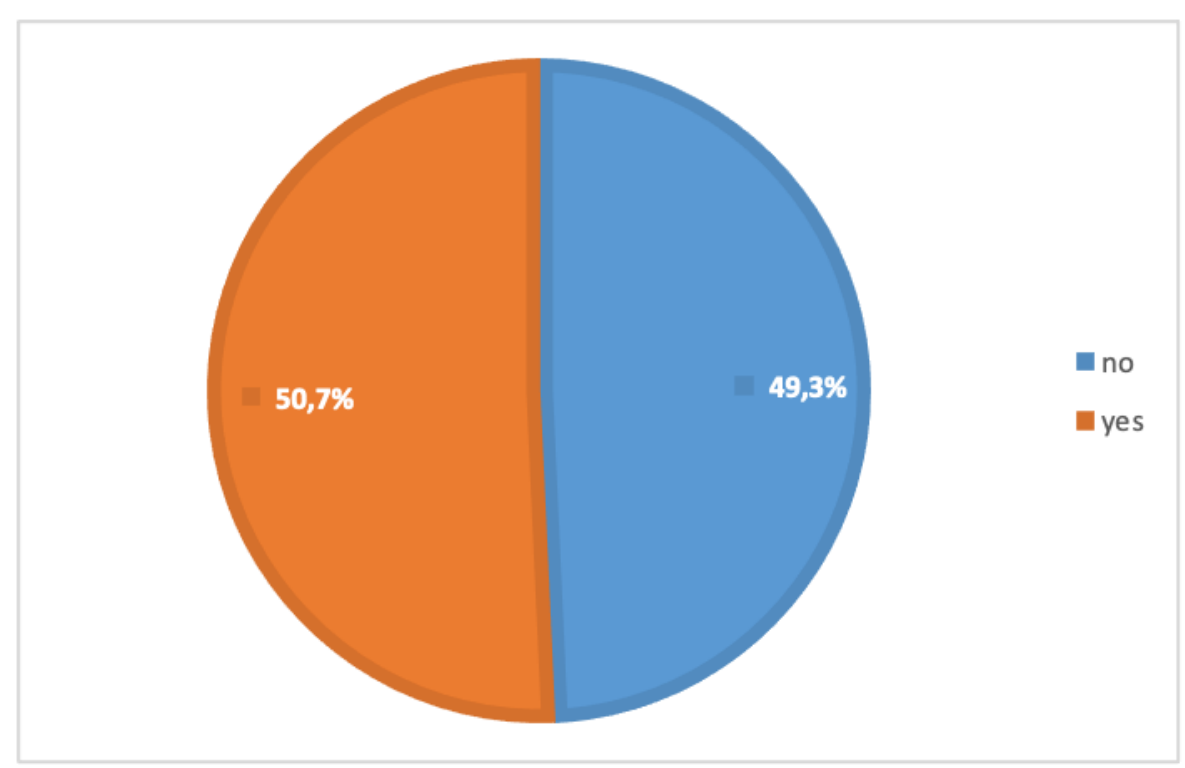

Figure 4. The level of studies in this field

Source: own elaboration

Totaling 137 answers to this question, do you have studies/qualifications in the field which you want to start the business? we found that $61.3 \%$ of young people applied and attended specialized courses in entrepreneurship and only $38.7 \%$ of them did not access such training programs.

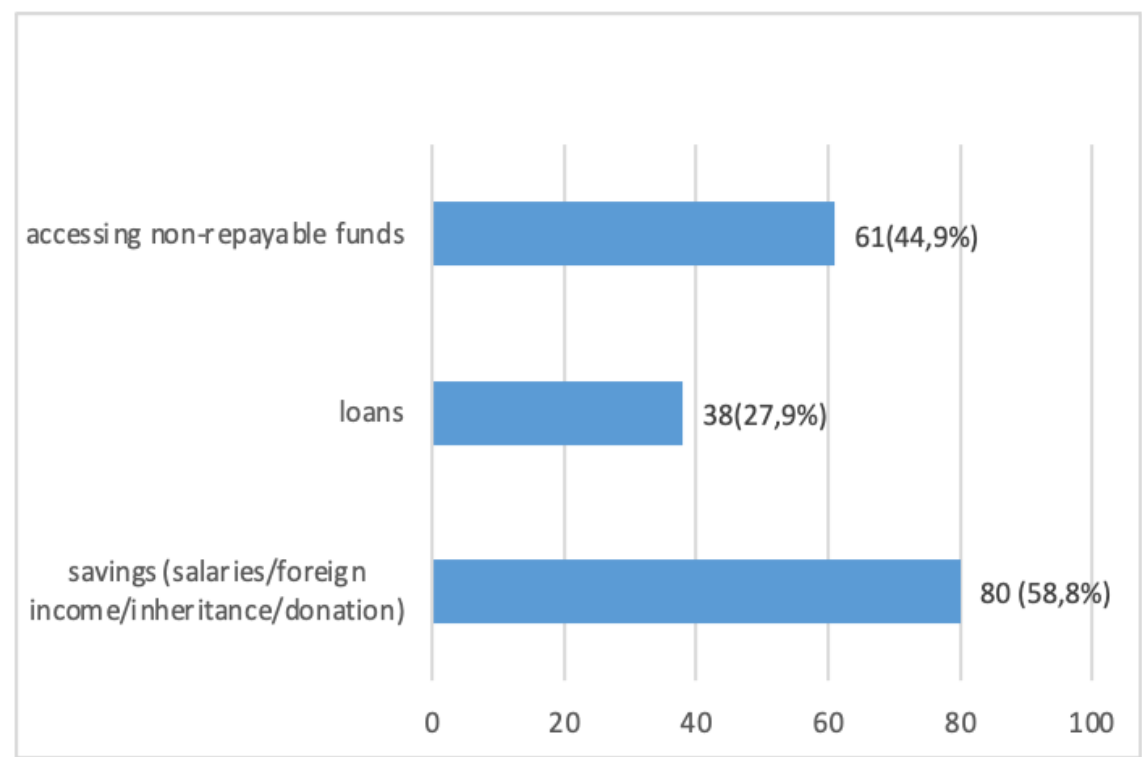

Figure 5. Sources of financing for opening the business

Source: own elaboration

Of the 136 answers received to this question, if you intend to initiate a business, specify from which sources the money comes from? about half of the young people surveyed, respectively $58.8 \%$, specified that the money they need to open their business comes from savings (salaries/income abroad/inheritance/donation). A percentage of $44.9 \%$ are willing to access non-reimbursable funds, and a percentage of $27.9 \%$ are willing to get money from loans to start a business. 


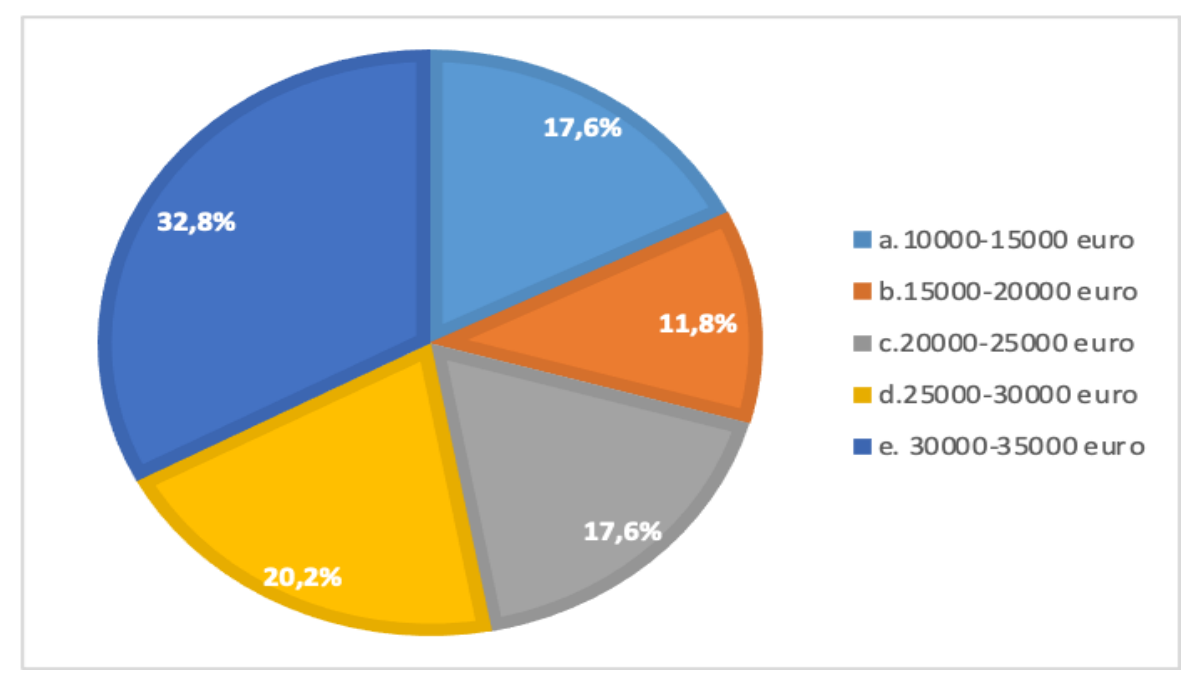

Figure 6. Estimation of the business financing budget

Source: own elaboration

A particularly important aspect of this study is the amount that young people think they need to start the business in the desired field. Of the 119 young people who answered this question, What amount do you think you need to start the business? $32.8 \%$ of them believe they need an amount between 30,000-35,000 euros, and 20.2\% of the amounts include between 25,000-30,000 euros. Only $11.8 \%$ consider that they need amounts between $15,000-20,000$ euros.

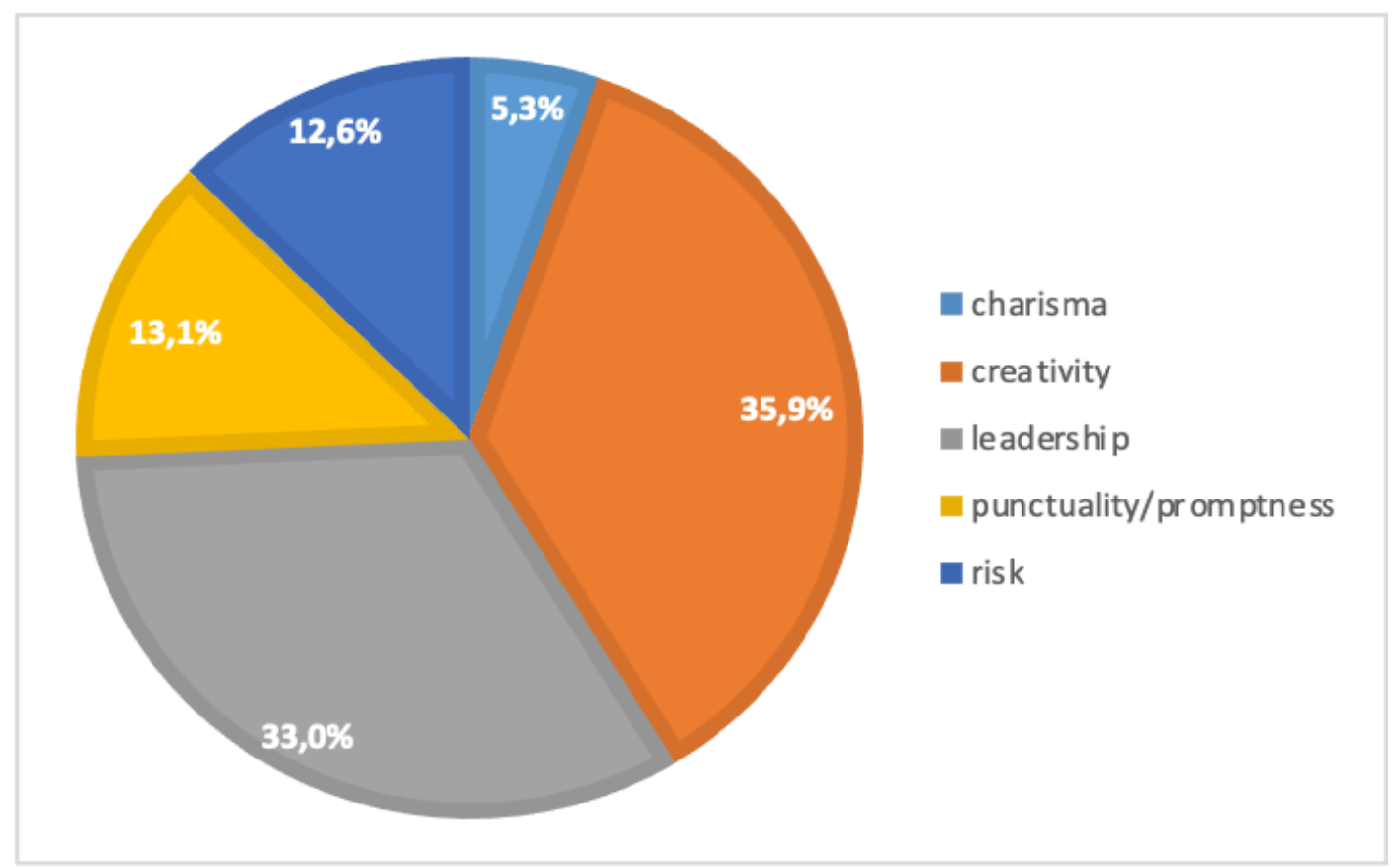

Figure 7. Important aspects of a successful entrepreneur

Source: own elaboration

At a rather small difference, creativity and leadership are considered by young people to be the most important traits of a successful entrepreneur. On the next places, also at a small difference, with a percentage of approx. 13\%, punctuality and risk are situated, and on the last place is charisma, with a percentage of only $5.3 \%$. 


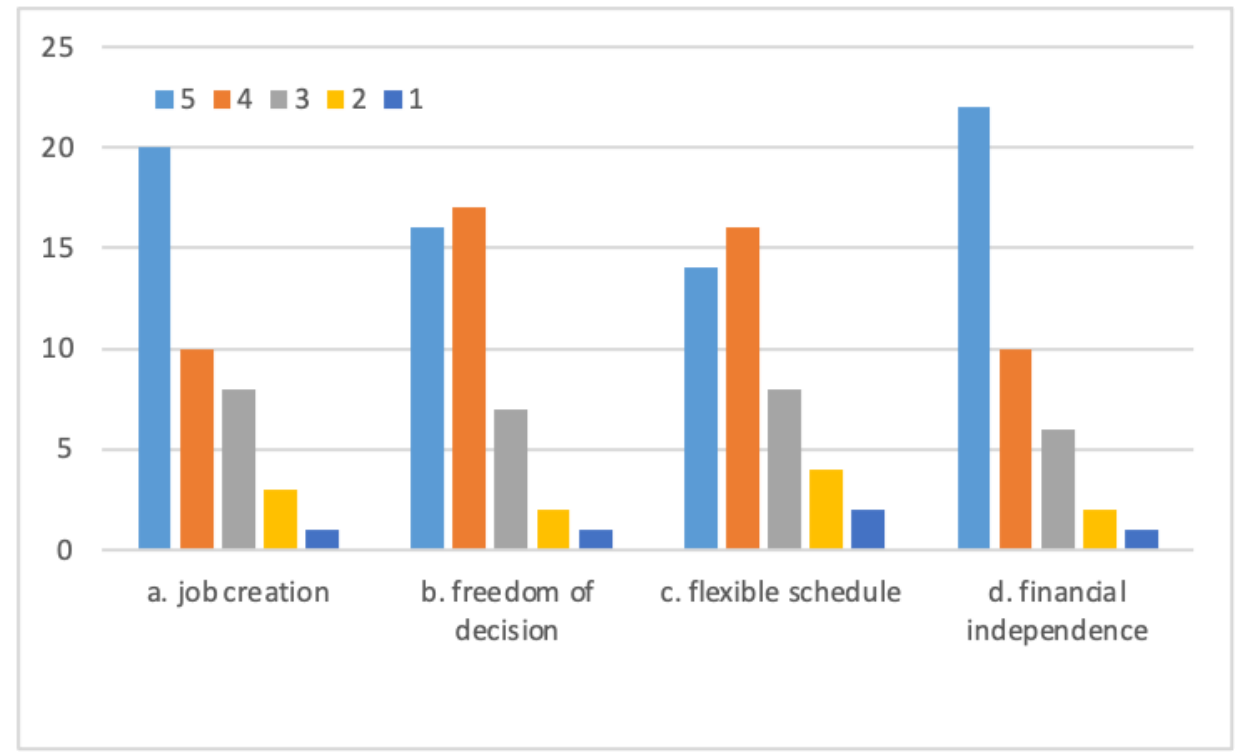

Figure 8. The advantages of starting a business

Source: own elaboration

Of the 4 advantages stated in the questionnaire, it seems that the most important is Financial Independence, the 2 nd place being the Creation of new jobs. Freedom of decision is also important in creating an advantage, and the Flexible Schedule makes most of the young people surveyed consider that it is also a great advantage.

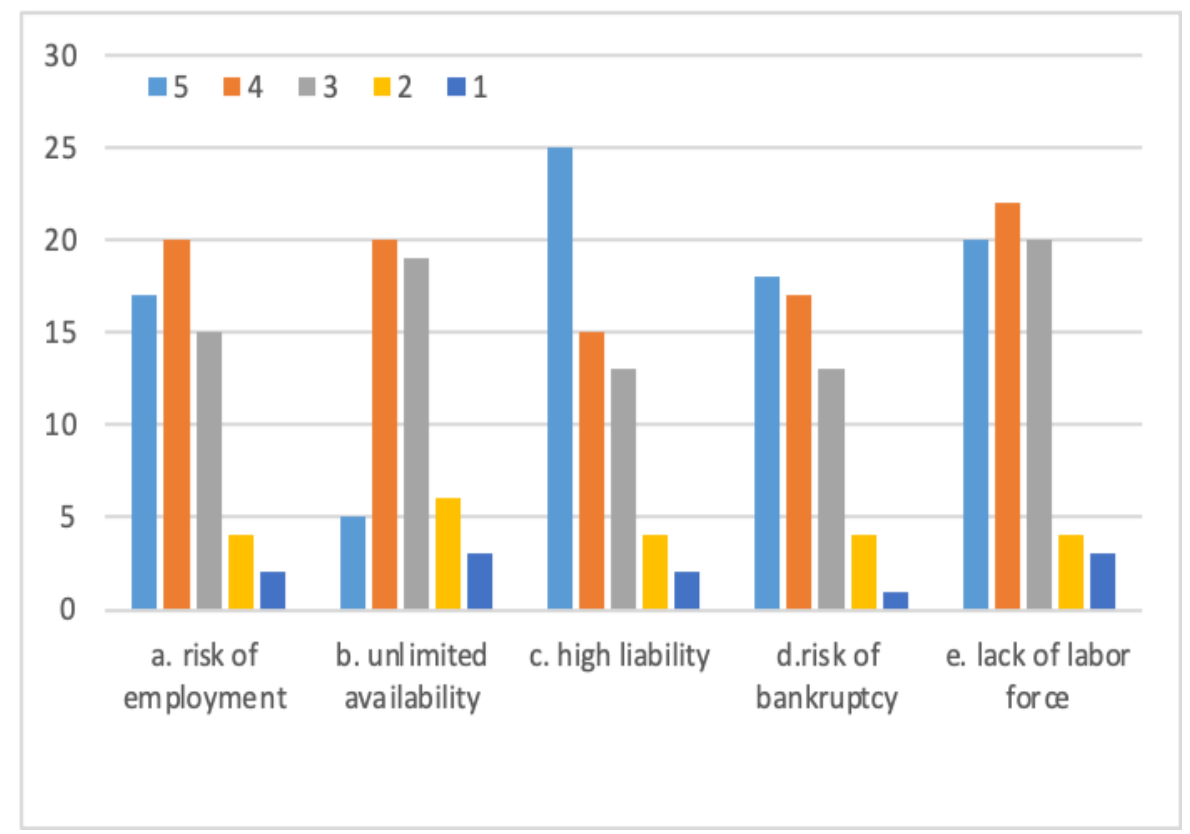

Figure 9. Disadvantages of starting a business

Source: own elaboration

As regards The Risk of Indebtedness, the young people who expressed their opinion considered that it represents a big disadvantage in opening a business. The biggest disadvantage, however, is considered to be The great responsibility that the future entrepreneur has in running his own business. The risk of bankruptcy is considered to be both a very high risk and a high risk by all 
those who have expressed their opinion, and The lack of labor is also considered to be a great disadvantage when opening a new business.

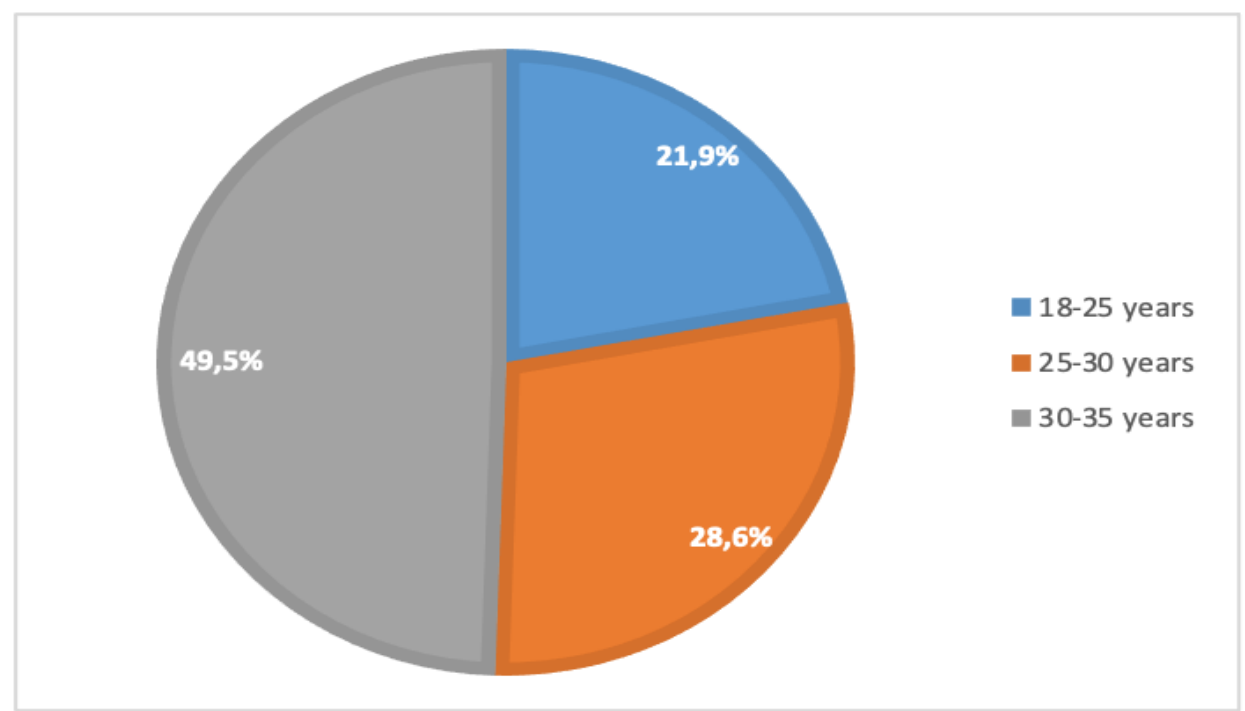

Figure 10. Age of respondents

Source: own elaboration

Registering 196 answers to this question, we found out that about half of the young people (49.5\%) are aged between 30-35 years, and the rest aged between 18-25 years and 25-30 years recorded a percentage of $21.9 \%$ and $28.6 \%$ respectively.

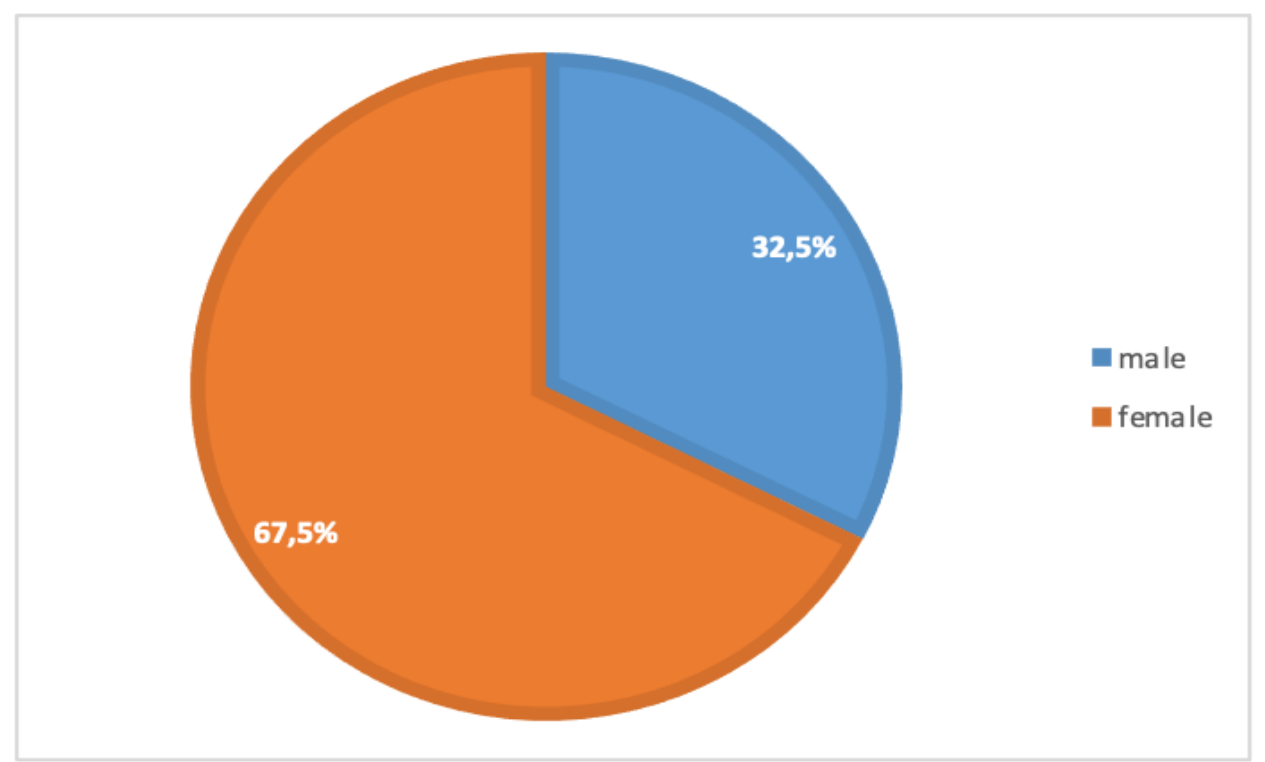

Figure 11. Gender of respondents

Source: own elaboration

Out of the 206 answers recorded to this question, we note that the vast majority of those who answered are women (67.1\%) and only $32.9 \%$ men and $60.8 \%$ among those interviewed have university degrees. 


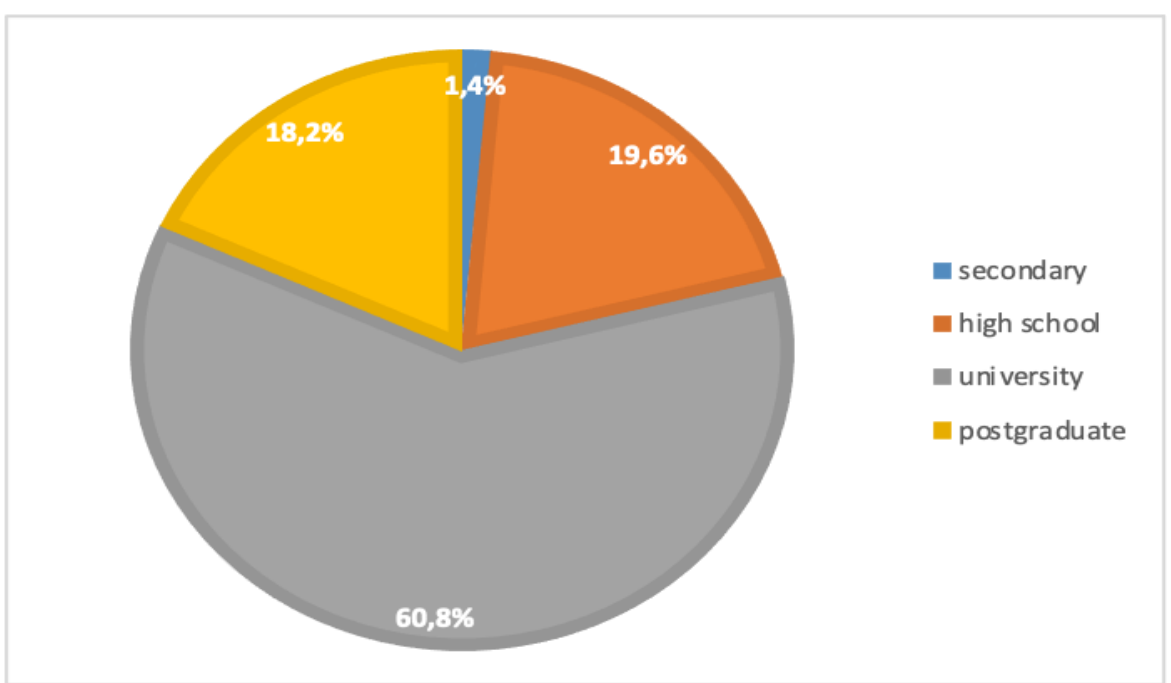

Figure 12. Level of education of respondents

Source: own elaboration

Table 4. Interpretation of statistical indicators

\begin{tabular}{|l|l|l|c|c|c|c|c|}
\hline & & & & \multicolumn{2}{|c|}{$\begin{array}{l}\text { Cumulative } \\
\text { frequencies }\end{array}$} & $\begin{array}{l}\text { Relative } \\
\text { frequencies }\end{array}$ \\
\hline $\begin{array}{l}\text { No. } \\
\text { crt. }\end{array}$ & $\begin{array}{l}\text { Contribution } \\
\text { to business } \\
\text { initiation } \\
\text { interval }\end{array}$ & $\begin{array}{l}\text { Young people } \\
\text { who want to } \\
\text { open a business }\end{array}$ & $\mathbf{X}_{\mathbf{i}}$ & $\sum \mathbf{x i} \cdot \boldsymbol{n i}$ & $\mathbf{N}_{\mathbf{i}} \uparrow$ & $\mathbf{N}_{\mathbf{i}} \downarrow$ & $\mathbf{f}$ \\
\hline $\mathbf{1 .}$ & $10.000-15.000$ & 22 & 12.500 & 262.500 & 22 & 119 & 18 \\
\hline $\mathbf{2 .}$ & $15.000-20.000$ & 14 & 17.500 & 245.000 & 36 & 97 & 12 \\
\hline $\mathbf{3 .}$ & $20.000-25.000$ & 20 & 22.500 & 427.500 & 56 & 83 & 17 \\
\hline $\mathbf{4 .}$ & $25.000-30.000$ & 24 & 27.500 & 687.500 & 80 & 63 & 20 \\
\hline $\mathbf{5 .}$ & $30.000-35.000$ & 39 & 32.500 & 1.300 .000 & 119 & 39 & 33 \\
\hline & TOTAL & $\mathbf{1 1 9}$ & & $\mathbf{2 . 9 2 2 . 5 0 0}$ & & & \\
\hline
\end{tabular}

Source: own elaboration

Most of the young people out of the 119 young people who want to open a business consider that they need 31,388.88 euros to be able to start the business and the average amount that the 119 young people consider they need to open a business is 24,559 euros.

\section{CONCLUSIONS}

In the modern economy, the development of firms is done through capital attracted from banks and financial markets. Given that Romanian entrepreneurs face much higher interest rates than in the rest of the European Union countries, about three quarters of SMEs rely on self-financing. At the same time, only $10 \%$ of SMEs concern accessing structurally non-reimbursable funds. The national unemployment rate is heading towards $4 \%$ but young people are still affected because $16 \%$ of young people up to the age of 24 are unemployed. It would be to everyone's advantage if the dynamic segment of young people were better encouraged in relation to the labour market.

Considering the general and statistical hypotheses formulated at the beginning of the research paper and following the centralization of the data from the completed casing sings, we conclude the following: 
Hypothesis 1: At most $40 \%$ of young people with entrepreneurship studies want to open a business. 49 young people out of the 119 young people who want to open a business have entrepreneurship studies, meaning $41.18 \%$. In this case, hypothesis 1 is refuted.

Hypothesis 2: At least $60 \%$ of the young people surveyed from Suceava without a job want to open a business. Only 5 young people out of the 119 young people who want to open a business do not have a job, meaning $4.20 \%$. In this case, hypothesis 2 is refuted.

Hypothesis 3: At most $80 \%$ of the young people surveyed want to open a business in the field of Services provision. Only 31 young people out of the 119 young people want to open a business in the field of Services provision, meaning $26.05 \%$. In this case, hypothesis 3 is confirmed.

Hypothesis 4: The amount that young people want to invest in a new business is at most 25,000 euros.

As a result of the calculation of the Media indicator, it turned out that the average amount that the 119 young people consider they need to open a business is 24,559 euros. In this case, hypothesis 4 is confirmed. During this analysis, through the results obtained from the completion of the questionnaire by young people aged between 18 and 35 years from Suceava, it was established that their involvement in the business environment is very important. The value of the study led to some clear results for those who are and will be interested in opening a business.

The training offer is made more and more visible, but it is not so accessible, as proof that many of the young people under investigation want to attend such courses in order to open their own business in the near future. Most information about a youth entrepreneurship initiative is knowledge networks and most seek to get in touch with people who have succeeded and who can be an example to follow later. It should be noted that the vast majority of young people are interested in opening a business in order to have a decent life and financial independence. However, we cannot overlook that there are many bottlenecks that can suppress the initiative of young people to open a business: the economic context, the lack of accessibility of funds, the limited possibility in terms of the capital needed to open a business.

\section{REFERENCES}

Chelcea S. (1975). Questionnaire in sociological investigation, Scientific Publishing House and Encyclopedic, Bucharest.

Ciobanu, O. G., Nastase, C. E., Neamțu, D.M. (2015). Generation Y: interconnected at local level with Romanian entreprenorial trends, Ecoforum Journal, 4(s-i 1), pp. 78-86.

Collins J. (2010). Excelența în afaceri (Business excellence), Editura Curtea Veche, București.

Cowen T. (2012). Creează-ti propria economie, Editura Publica.

Fuhrman J. (2012). Drumul spre leadership, Editura Curtea Veche, București.

Global Entrepreneurship Monitor, (2010). Entrepreneurship in Romania, Country Report.

Good Small Business Guide, (2013). How to Start and Grow your Own Business, Editura Bloomsbury Publishing Plc.

Jelescu, P., \& Elpujan, O. (2016). Entrepreneurship - an imperative in the professional training of specialists. In: Materials of the International Scientific Conference "Higher Education: Valences and Educational, Research and Innovational Transfer Opportunities", State University of Moldova. Chisinau: CEP USM.

Marinescu, M., \& Botea, M. (2017). Approach to entrepreneurship education among students. In: Studia Universitatis Moldaviae, 2017, nr. 5(105) Series "Educational Sciences" ISSN 1857-2103. 
Neamţu, D. M. (2017). The University - An Entrepreneurial and Innovative Higher Education Institution, 11th International Technology, Education and Development Conference, INTED 2017 Proceedings, 6-8 March, Valencia, Spain

Neamţu, D. M., \& Ciobanu, O. (2017). Business and entrepreneurship - mutations and structural changes due to the transition to Knowledge economy, Strategica -International Conference Fifth Edition, "Shift! Major Challenges of Today's Economy", Bucharest: 28th -30th September.

Roibu, P. A. (2019). Entrepreneur - Important factor in economic growth and development. Within the project "Support for $\mathrm{PhD}$ students in the field of economic sciences", POSDRU/187/1.5/S/155656. Bucharest: Publishing House ASE.

Rothbard, M. N. (1997). Toward a Reconstruction of Utility and Welfare Economics, în Logic of Action One, Edward Elgar, Cheltenham, U.K.

https://www.business-academy.ro/ce-face-un-antreprenor

https://www.onrc.o/index.php/ro/statistici?id=243

https://emanageri.wordpress.com/2014/02/14/rolul-antreprenorilor-in-societate-si-cum-staromania-la-acest-capitol/

https://files.finantare.ro/2014/studiu-EY-barometrul-educatiei-si-culturii-antreprenoriale.pdf https://www.ecoduri.com/search_date_demografice.php?judetmare=Suceava/Suceava\#statist ici_demografice 